Article

\title{
Oxoisoaporphine as Potent Telomerase Inhibitor
}

\author{
Zu-Zhuang Wei ${ }^{\dagger}$, Qi-Pin Qin ${ }^{\dagger}$, Jia-Nian Chen and Zhen-Feng Chen ${ }^{*}$ \\ State Key Laboratory for Chemistry and Molecular Engineering of Medicinal Resources, \\ School of Chemistry and Pharmacy, Guangxi Normal University, 15 Yucai Road, Guilin 541004, China; \\ weizuzhuang@126.com (Z.-Z.W.); qinqipin2007@126.com (Q.-P.Q.); cjn288@sina.com (J.-N.C.) \\ * Correspondence: chenzf@gxnu.edu.cn; Tel./Fax: +86-773-212-0958 \\ + These authors contributed equally to this work.
}

Academic Editor: Diego Muñoz-Torrero

Received: 4 September 2016; Accepted: 5 November 2016; Published: 14 November 2016

\begin{abstract}
Two compounds previously isolated from traditional Chinese medicine, Menispermum dauricum (DC), 6-hydroxyl-oxoisoaporphine (H-L $\left.\mathrm{L}^{\mathrm{a}}\right)$, and 4,6-di(2-pyridinyl)benzo[ $\left.h\right]$ isoindolo[4,5,6-de]

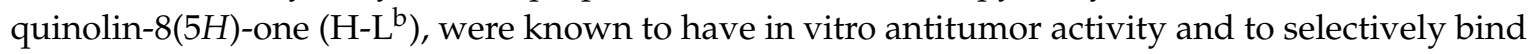
human telomeric, c-myc, and bcl-2 G-quadruplexes (G4s). In this study, the binding properties of these two compounds to telomerase were investigated through molecular docking and telomeric repeat amplication protocol and silver staining assay (TRAP-silver staining assay). The binding energies bound to human telomerase RNA were calculated by molecular docking to be -6.43 and $-9.76 \mathrm{kcal} / \mathrm{mol}$ for $\mathrm{H}-\mathrm{L}^{\mathrm{a}}$ and $\mathrm{H}-\mathrm{L}^{\mathrm{b}}$, respectively. Compared with $\mathrm{H}-\mathrm{L}^{\mathrm{a}}$, the ligand $\mathrm{H}-\mathrm{L}^{\mathrm{b}}$ more strongly inhibited telomerase activity in the SK-OV-3 cells model.
\end{abstract}

Keywords: oxoisoaporphine; telomerase; molecular docking

\section{Introduction}

Previous studies found that telomerase enzyme complexes or telomerase inhibitors play a key role in tumorigenesis and telomere maintenance, and suggested that these structures may be an entry point for devising novel anticancer drugs [1-3]. Various strategies have been proposed to inhibit telomerase in cellular immortalization. A promising method among them aims to disrupt the telomere-telomerase interaction with small molecules as interfering ligands. The ligand binds the enzyme substrate to prevent telomere elongation or formation of the telomere-telomerase complex [4,5]. In addition, a large number of G4s structural studies have shown that telomeric DNA terminates in a single-stranded $3^{\prime}$ over hang which can form higher-order conformations termed G4s, such as telomeric, bcl-2, and c-myc G-quadruplexes (G4s) [6-9]. Therefore, small molecules that selectively bind and stabilize these structures (e.g., telomeric G4 and other G4s DNA) can influence telomere maintenance and potentially serve as therapeutic agents [1-9].

In addition, it has been reported that the identification of proteins in eukaryotic cells that recognize, generate, or alter G4s in vitro with remarkable specificity suggests that these structures were formed in vivo $[10,11]$. Because human tumor cells and numerous neoplasia have been found to be accompanied with aberrant telomere length regulation, potent G-quadruplexes (G4 DNAs) with high selectivity against human cancer cells and low toxicity against normal cells are considered as new molecular target in cancer therapeutics [12]. Furthermore, the formation of G4 (G-quadruplex) by telomeric DNA inhibits the activity of telomerase, an enzyme not found in most normal somatic cells, but present in $85 \%-90 \%$ of cancer/tumor cells and contributing to the immortality of these cells [12]. It has been hypothesized that telomerase has to be reactivated in order to maintain telomere length, and consequently allow tumor cells to undergo sustained proliferation. Hence, novel G4s ligands that can target telomerase are deemed to be promising therapeutic agents [13-15]. 
Natural and synthetic alkaloids (including liriodenine, formamide oxoaporphine, oxoisoaporphine, and its derivatives, etc.) and their complexes are important molecules that bind G4s (such as bcl-2, telomere, and/or c-myc G4s) [16]. A small number of formamide oxoaporphine and oxoisoaporphine metal complexes are reported to be G-quadruplex ligands or telomerase inhibitors [17-21]. In this paper, we use molecular docking and a TRAP-silver staining assay (telomeric repeat amplication protocol and silver staining assay) to investigate the binding properties of two oxoisoaporphine ligands (6-hydroxyl-oxoisoaporphine, H-L ${ }^{a}$ [19]; and 6-di(2-pyridinyl)benzo[ $\left.h\right]$ isoindolo[4,5,6-de]quinolin$8(5 H)$-one, ${\mathrm{H}-\mathrm{L}^{\mathrm{b}}}^{[21]}$ ) to telomerase (Figure 1 ).

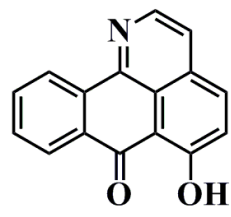

H-L $\mathbf{L}^{\mathrm{a}}$

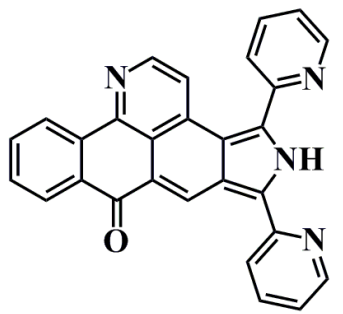

H-L ${ }^{b}$

Figure 1. Chemical structure of oxoisoaporphine ligands $\mathrm{H}-\mathrm{L}^{\mathrm{a}}$ (6-hydroxyl-oxoisoaporphine) and $\mathrm{H}-\mathrm{L}^{\mathrm{b}}$ (6-di(2-pyridinyl)benzo[ $h]$ isoindolo[4,5,6-de]quinolin-8(5H)-one).

\section{Results and Discussion}

\subsection{Molecular Docking}

Molecular docking analyses were performed using the AutoDock software (Version: 4.2.6, The Scripps Research Institute, La Jolla, CA, USA) in order to investigate the probable binding mode between the ligand $\left(\mathrm{H}-\mathrm{L}^{\mathrm{a}}\right.$ and $\left.\mathrm{H}-\mathrm{L}^{\mathrm{b}}\right)$ and human telomerase. Human telomerase is the enzyme that maintains the length of telomeres, which mainly consists of three components: a core reverse transcriptase protein (hTERT), telomerase RNA (hTR), and several species-specific proteins [22]. Despite its significance as an almost universal cancer target, the understanding of human telomerase and the development of specific inhibitors have been hampered by the limited data about this enzyme's three-dimensional structure. To date, the crystal structures of hTERT and hTR have not been reported, though other species' telomerases-such as the telomerases of Tetrahymena thermophila and Tribolium castaneum - have already been decoded several years before [23-25]. Therefore, in many reports, the molecular docking analyses of the inhibitors is mainly based on non-human species' telomerases [25], though as we all know, the human telomerase structure is very different from that of other species. In this study, with the aid of the receptor model (PDB code: 2INA) which has been reported previously [22,26], the above two ligands were successfully docked into the hTR pocket for the first time (Figure 2). As shown in Figure 2A, hTR consists of four intertwined chains: a (in green), b (in blue), c (in red), and d (in yellow). The ligand $\mathrm{H}-\mathrm{L}^{\mathrm{a}}$ was mainly interacted with the chains a and $\mathrm{d}$, and two H-bonds were formed. The first H-bond with a distance of $2.0 \AA$ formed between 7-carbonyl oxygen atom of $\mathrm{H}-\mathrm{L}^{\mathrm{a}}$ and a hydrogen atom in the base moiety $\mathrm{C}-151$ of chain a (in Figure $2 \mathrm{~B}$, "C-151" refers to NO. 151 cytidine). The second H-bond with a distance of $2.2 \AA$ formed between one 6-hydroxy group $(\mathrm{OH})$ of the ligand and the oxygen atom in the nucleoside moiety $(\mathrm{OH} \cdots \mathrm{O})$ of chain a. Chains a and $d$ were helically wound and formed a larger pocket, in which the ligand $\mathrm{H}-\mathrm{L}^{\mathrm{a}}$ was easily embedded (Figure $2 \mathrm{C}$ ). Very different to the ligand $\mathrm{H}-\mathrm{L}^{\mathrm{a}}$, the first two $\mathrm{H}$-bonds were formed between two nitrogen atoms of $\mathrm{H}-\mathrm{L}^{\mathrm{b}}$ and cytidine bases (C-148 and C-149), the third H-bond with a distance of $2.3 \AA$ was formed between the nitrogen atom in another pyridine unit of $\mathrm{H}_{-} \mathrm{L}^{\mathrm{b}}$ and adenosine base (A-150); simultaneously, the sole carbonyl oxygen atom of $\mathrm{H}-\mathrm{L}^{\mathrm{b}}$ formed the fourth H-bond (CO ‥HN) with a distance of $2.2 \AA$ (Figure 2D). As described above, because the binding pocket could hold those molecules with larger volume, the ligand H-L ${ }^{b}$ could be almost perfectly 
embedded in this active pocket (Figure 2E). The binding energies bound to hTR were calculated to be -6.43 and $-9.76 \mathrm{kcal} / \mathrm{mol}$ for $\mathrm{H}-\mathrm{L}^{\mathrm{a}}$ and $\mathrm{H}-\mathrm{L}^{\mathrm{b}}$, respectively. In the binding model, the ligand $\mathrm{H}_{-} \mathrm{L}^{\mathrm{b}}$ was surrounded by a thick "fog" formed by chains a and d (Figure 2F). In our opinion, compared with $\mathrm{H}-\mathrm{L}^{\mathrm{a}}$, besides an additional two H-bonds, the more suitable molecular volume of $\mathrm{H}_{-} \mathrm{L}^{\mathrm{b}}$ resulted in stronger affinity to hTR. The molecular docking results further supported the previous hypothesis that $\mathrm{H}-\mathrm{L}^{\mathrm{b}}$ was more cytotoxic and could more strongly inhibit telomerase.
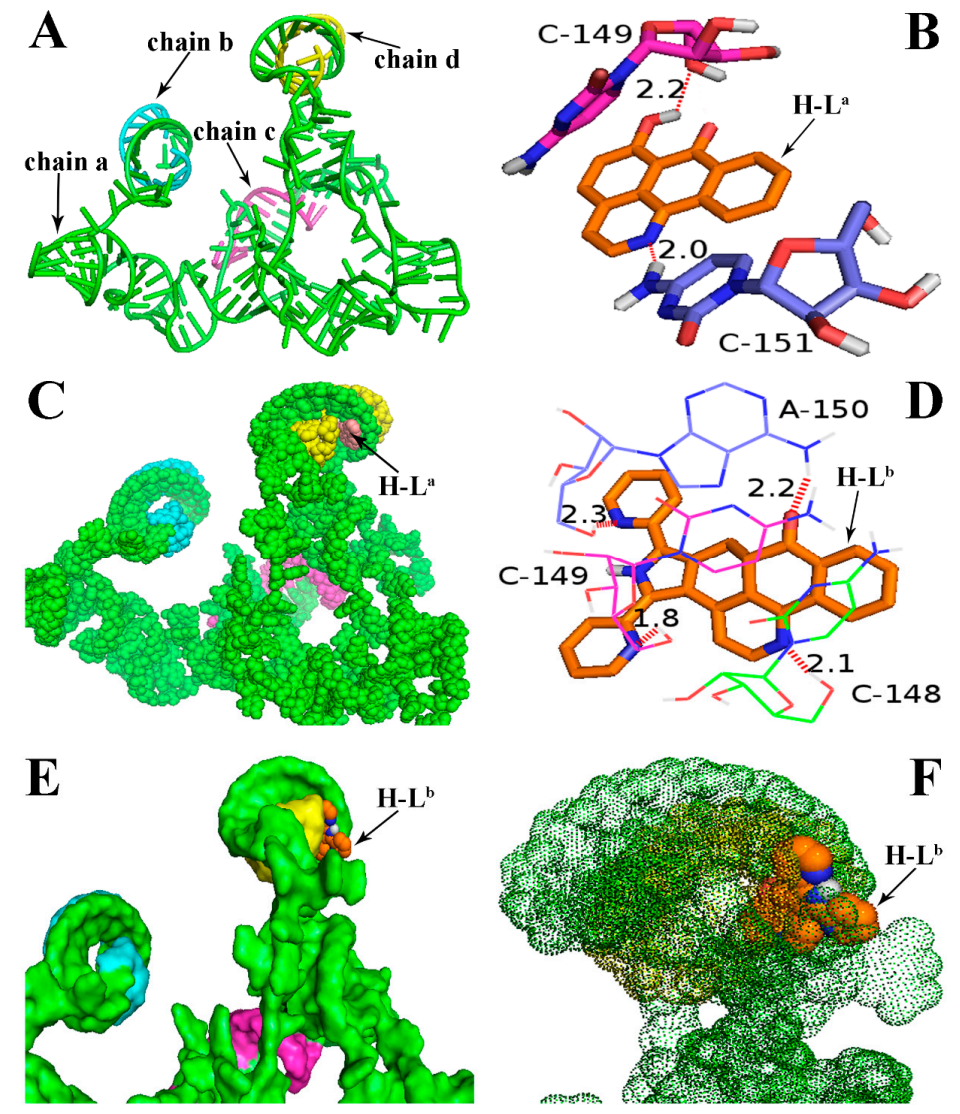

Figure 2. Binding mode of the ligands $H-L^{a}$ and $H-L^{b}$ with human telomerase RNA (hTR). (A) Three-dimensional conformation model of hTR (PDB ID: 2INA), which was not reported in the RCSB protein data bank (http: / www.rcsb.org). The bases and chains are represented as a cartoon; (B) Two H-bonds were formed between $\mathrm{H}-\mathrm{L}^{\mathrm{a}}$ and the receptor 2INA; (C) $\mathrm{H}-\mathrm{L}^{\mathrm{a}}$ was embedded in the active pocket; (D) Four H-bonds were formed between $\mathrm{H}-\mathrm{L}^{\mathrm{b}}$ and the receptor 2INA; $(\mathbf{E}, \mathbf{F}) \mathrm{H}_{-} \mathrm{L}^{\mathrm{b}}$ was surrounded by a "fog" formed by chains a and d. In Figure 2B,D, the ligands are represented as ball-and-stick models and colored by atom type. Hydrogen bonds are represented by red dotted lines. White: hydrogen atom; red: oxygen atom; dark blue: nitrogen atom; orange: the backbone and carbon atom of the ligands $\mathrm{H}-\mathrm{L}^{\mathrm{a}}$ and $\mathrm{H}-\mathrm{L}^{\mathrm{b}}$.

\subsection{In Vitro Cytotoxicity}

The $\mathrm{IC}_{50}$ values of the two oxoisoaporphine ligands $\mathrm{H}-\mathrm{L}^{\mathrm{a}}$ and $\mathrm{H}-\mathrm{L}^{\mathrm{b}}$ were measured using the 3-(4,5-dimethylthiazol-2-yl)-2,5-diphenyltetrazolium bromide (MTT) method against the human normal liver HL-7702 cell line [19,21] and several human cancer cell lines (including T-24, HCT-8, Hep-G2, SK-OV-3/DDP, SK-OV-3, BEL-7402, and NCI-H460 tumor cells). Figure 3 shows that, compared with $\mathrm{H}-\mathrm{L}^{\mathrm{a}}, \mathrm{H}-\mathrm{L}^{\mathrm{b}}$ exhibited stronger cytotoxicity against all tested cell lines except SK-OV-3/DDP. Notably, H-L ${ }^{b}$ was approximately $250 \%$ more potent than H-L against SK-OV-3 cells. Therefore, we further studied the inhibition of telomerase activity in SK-OV-3 cells by the two oxoisoaporphine ligands $\mathrm{H}-\mathrm{L}^{\mathrm{a}}(100 \mu \mathrm{M})$ and $\mathrm{H}^{-\mathrm{L}^{\mathrm{b}}}\left(\mathrm{IC}_{50}=39.5 \mu \mathrm{M}\right)$ through TRAP-silver staining assay. 


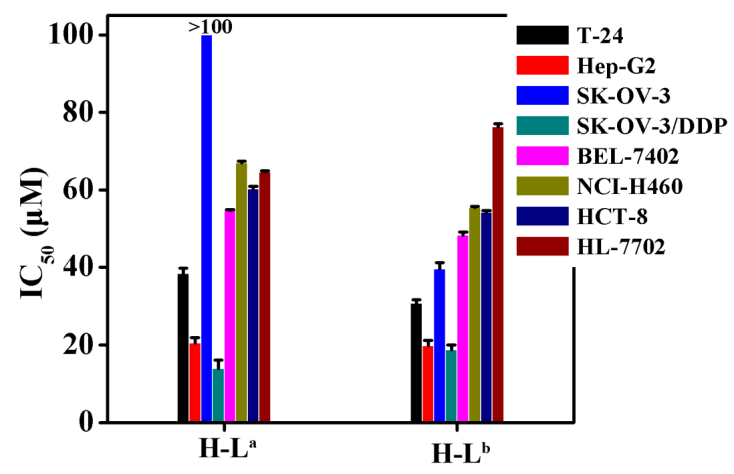

Figure 3. $\mathrm{IC}_{50}$ values $(\mu \mathrm{M})$ of $\mathrm{H}-\mathrm{L}^{\mathrm{a}}$ and $\mathrm{H}-\mathrm{L}^{\mathrm{b}}$ for selected cells (T-24, HCT-8, Hep-G2, SK-OV-3/DDP, BEL-7402, HL-7702, SK-OV-3 and NCI-H460 human cell lines).

\subsection{Telomerase Activity Inhibition Studies by TRAP-Silver Staining Assay}

Recent studies found that about $80 \%-90 \%$ of various cancer cells have detectable telomerase activity; telomerase is therefore believed to be a potential anticancer target $[27,28]$. The results of the MTT assay and molecular docking suggested that it was of interest to compare to what extent the two oxoisoaporphine ligands $\mathrm{H}-\mathrm{L}^{\mathrm{a}}$ and $\mathrm{H}-\mathrm{L}^{\mathrm{b}}$ could inhibit telomerase activity in SK-OV-3 cells. This comparison was made by running the telomerase activity inhibition studies by the TRAP-silver staining assay with the two oxoisoaporphine ligands. As shown in Figure 4, the number of bands clearly decreased with each compound, showing that the telomerase activity was reduced by $64.98 \%$ when $39.5 \mu \mathrm{M} \mathrm{H}-\mathrm{L}^{\mathrm{b}}$ was applied, whereas the reduction was only $37.22 \%$ when $100 \mu \mathrm{M} \mathrm{H}-\mathrm{L}^{\mathrm{a}}$ was applied. This result was in good agreement with the results of MTT assay and molecular docking.

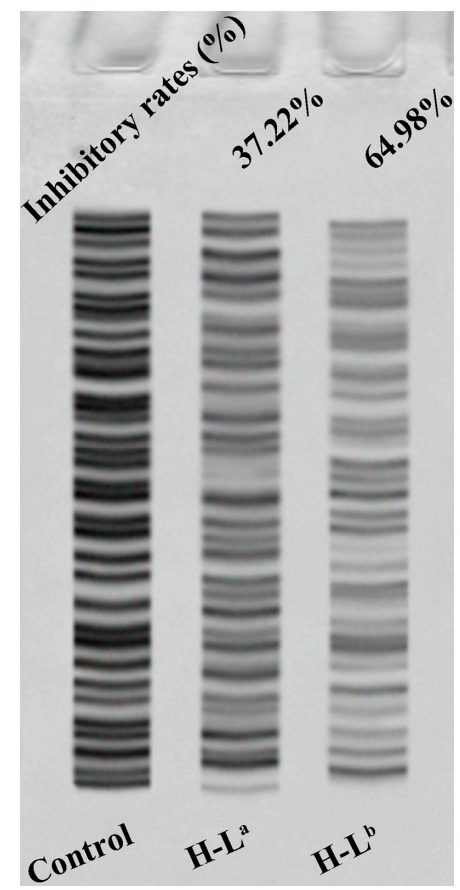

Figure 4. The inhibition of telomerase in SK-OV-3 cells by oxoisoaporphine ligands.

\section{Experimental Methods}

\subsection{Materials and Instrumentation}

The human normal liver cell line HL-7702 and the human cancer cell lines HCT-8, T-24, SK-OV-3/DDP, Hep-G2, SK-OV-3, BEL-7402, and NCI-H460 were obtained from the Institute of 
Biochemistry and Cell Biology, Chinese Academy of Sciences (Shanghai, China). The two test compounds were stored as stock solutions $(2.0 \mathrm{mM})$ in DMSO, and further diluted with appropriate buffer to working concentrations (e.g., $100 \mu \mathrm{M}$ of H-L and $39.5 \mu \mathrm{M}$ of $\mathrm{H}-\mathrm{L}^{\mathrm{b}}$, respectively) when needed. MTT assay was performed on an M1000 microplate reader (Tecan Trading Co. Ltd., Shanghai, China).

\subsection{Synthesis of Oxoisoaporphine Ligands}

The two oxoisoaporphine ligands $\mathrm{H}-\mathrm{L}^{\mathrm{a}}$ and $\mathrm{H}-\mathrm{L}^{\mathrm{b}}$ were prepared according to the procedures previously reported by Chen and co-workers $[19,21]$.

\subsection{MTT Assay and Telomerase Activity Assay}

The MTT assay and the telomerase activity assay by TRAP-silver staining assay followed the regular settings reported in previous work $[20,21,29,30]$.

\subsection{Docking Study}

A docking study was performed using the AutoDock software (Version: 4.2.6, The Scripps Research Institute) in combination with MGLTools (Version: 1.5.6, The Scripps Research Institute) and PyMOL (Version: 1.7, Schrödinger Inc., New York, NY, USA) to explore the interactions between the ligands ( $\mathrm{H}-\mathrm{L}^{\mathrm{a}}$ and $\mathrm{H}-\mathrm{L}^{\mathrm{b}}$ ) and hTR (PDB ID: 2INA), and to visualize the probable binding mode. All calculations were carried out on a Linux station $(4 \times 2$ cores) running Centos 7 . The three-dimensional structures of the two ligands were constructed using ChemBio3D Ultra 12.0 (Cambridge Soft Corporation, Cambridge, MA, USA) and then energetically minimized. They were then molecularly modeled using AutoDock. The 3D structure model of hTR can be obtained by the conversion of the data downloaded from the Protein Data Bank (http:/ /www.rcsb.org, PDB ID: 2INA) using PyMOL, and the resulting image is shown in Figure 2A. Prior to molecular modeling, polar hydrogen atoms were added [22-26,31,32]. In the docking model, a grid $(100 \times 100 \times 100 \AA)$ was set, and the binding energies were obtained by AutoDock scoring function. After the complex of the ligand bound to the receptor was obtained, the following analyses were carried out using PyMOL software (Version: 1.7, Schrödinger Inc., New York, NY, USA).

\section{Conclusions}

The binding affinity of two oxoisoaporphine ligands toward telomerase was evaluated by molecular docking. The ligand $\mathrm{H}-\mathrm{L}^{\mathrm{a}}$ could form two hydrogen bonds with telomerase in the complex, whereas the ligand $\mathrm{H}-\mathrm{L}^{\mathrm{b}}$ could form four hydrogen bonds in the complex. The calculated binding energies of $\mathrm{H}-\mathrm{L}^{\mathrm{a}}$ and $\mathrm{H}-\mathrm{L}^{\mathrm{b}}$ with $\mathrm{hTR}$ were -6.43 and $-9.76 \mathrm{kcal} / \mathrm{mol}$, respectively. To examine the abilities of two oxoisoaporphine ligands to bind strongly to the telomerase inhibitory activity and to inhibit cancer proliferation, we also performed a TRAP assay and in vitro cytotoxicity studies of ligands $\mathrm{H}-\mathrm{L}^{\mathrm{a}}$ and $\mathrm{H}-\mathrm{L}^{\mathrm{b}}$. The results indicated that $\mathrm{H}-\mathrm{L}^{\mathrm{b}}$ was a potent inhibitor of telomerase and SK-OV-3 cell proliferation, and might be a potential lead compound for the development of a new telomerase inhibitor.

Acknowledgments: This work was supported by the National Natural Science Foundation of China (Grants 21431001, 81473102, 21271051), CMEMR2012-A01, CMEMR2012-A22, CMEMR2016-A05, IRT_16R15, NNSF of Guangxi of China (2016GXNSFGA380005) and "BAGUI Scholar" program of Guangxi Province of China, as well as Innovation Project of Guangxi Graduate Education (YCBZ2015024).

Author Contributions: Z.-Z.W., Q.-P.Q. and Z.-F.C. conceived and designed the experiments. Q.-P.Q. and Z.-Z.W. performed the experiments. J.-N.C. contributed to the molecular docking of two oxoisoaporphine ligands. Z.-Z.W., Q.-P.Q. and Z.-F.C. analyzed data, reviewed and edited the paper. All authors read and approved the manuscript.

Conflicts of Interest: The authors declare no conflicts of interest. 


\section{References}

1. Rezler, E.M.; Bearss, D.J.; Hurley, L.H. Telomeres and telomerases as drug targets. Curr. Opin. Pharmacol. 2002, 2, 415-423. [CrossRef]

2. Balasubramanian, S.H.; Hurley, L.H.; Neidle, S. Targeting G-quadruplexes in gene promoters: A novel anticancer strategy? Nat. Rev. Drug Discov. 2011, 10, 261-275. [CrossRef] [PubMed]

3. Xu, Y. Chemistry in human telomere biology: Structure, function and targeting of telomere DNA/RNA. Chem. Soc. Rev. 2011, 40, 2719-2740. [CrossRef] [PubMed]

4. Sekaran, V.; Soares, J.; Jarstfer, M.B. Telomere maintenance as a target for drug discovery. J. Med. Chem. 2014, 57, 521-538. [CrossRef] [PubMed]

5. Mergny, J.L.; Riou, J.F.; Mailliet, P.; Teulade-Fichou, M.P.; Gilson, E. Natural and pharmacological regulation of telomerase. Nucleic Acids Res. 2002, 30, 839-865. [CrossRef] [PubMed]

6. Phan, A.T.; Patel, D.J. Two-repeat human telomeric d(TAGGGTTAGGGT) sequence forms interconverting parallel and antiparallel G-quadruplexes in solution: Distinct topologies, thermodynamic properties, and folding/unfolding kinetics. J. Am. Chem. Soc. 2003, 125, 15021-15027. [CrossRef] [PubMed]

7. Ying, L.; Green, J.J.; Li, H.; Klenerman, D.; Balasubramanian, S. Studies on the structure and dynamics of the human telomeric G quadruplex by single-molecule fluorescence resonance energy transfer. Proc. Natl. Acad. Sci. USA 2003, 100, 14629-14634. [CrossRef] [PubMed]

8. Parkinson, G.N.; Lee, M.P.; Neidle, S. Crystal structure of parallel quadruplexes from human telomeric DNA. Nature 2002, 417, 876-880. [CrossRef] [PubMed]

9. Neidle, S.; Parkinson, G.N. The structure of telomeric DNA. Curr. Opin. Struct. Biol. 2003, 13, $275-283$. [CrossRef]

10. Baran, N.; Pucshansky, L.; Marco, Y.; Benjamin, S.; Manor, H. The SV40 large T-antigen helicase can unwind four stranded DNA structures linked by G-quartets. Nucleic Acids Res. 1997, 25, 297-303. [CrossRef] [PubMed]

11. Sun, H.; Yabuki, A.; Maizels, N. A human nuclease specific for G4 DNA. Proc. Natl. Acad. Sci. USA 2001, 98, 12444-12449. [CrossRef] [PubMed]

12. Kim, N.W.; Piatyszek, M.A.; Prowse, K.R.; Harley, C.B.; West, M.D.; Ho, P.L.C.; Coviello, G.M.; Wright, W.E.; Weinrich, S.L.; Shay, J.W. Specific association of human telomerase activity with immortal cells and cancer. Science 1994, 266, 2011-2015. [CrossRef] [PubMed]

13. Amrane, S.; Kerkour, A.; Bedrat, A.; Vialet, B.; Andreola, M.L.; Mergny, J.L. Topology of a DNA G-qudruplex structure formed in the HIV-1 promoter: A potential target for anti-HIV drug development. J. Am. Chem. Soc. 2014, 136, 5249-5252. [CrossRef] [PubMed]

14. Paritala, H.; Firestine, S.M. Characterization of insulin ILPR sequences for their ability to adopt a G-quadruplex structure. Nucleosides Nucleotides Nucleic Acids 2010, 29, 81-90. [CrossRef] [PubMed]

15. Bochman, M.L.; Paeschke, K.; Zakian, V.A. DNA secondary structures: Stability and function of G-quadruplex structures. Nat. Rev. Genet. 2012, 13, 770-780. [CrossRef] [PubMed]

16. Xiong, Y.-X.; Huang, Z.-S.; Tan, J.-H. Targeting G-quadruplex nucleic acids with heterocyclic alkaloids and their derivatives. Eur. J. Med. Chem. 2015, 97, 538-551. [CrossRef] [PubMed]

17. Li, Y.-L.; Qin, Q.-P.; Liu, Y.-C.; Chen, Z.-F.; Liang, H. A platinum(II) complex of liriodenine from traditional Chinese medicine (TCM): Cell cycle arrest, cell apoptosis induction and telomerase inhibition activity via G-quadruplex DNA stabilization. J. Inorg. Biochem. 2014, 137, 12-21. [CrossRef] [PubMed]

18. Chen, Z.-F.; Qin, Q.-P.; Qin, J.-L.; Zhou, J.; Li, Y.-L.; Li, N.; Liu, Y.-C.; Liang, H. Water-soluble ruthenium(II) complexes with chiral 4-(2,3-Dihydroxypropyl)-formamide oxoaporphine (FOA): In vitro and in vivo anticancer activity by stabilization of G-quadruplex DNA, inhibition of telomerase activity, and induction of tumor cell apoptosis. J. Med. Chem. 2015, 58, 4771-4789. [CrossRef] [PubMed]

19. Chen, Z.-F.; Qin, Q.-P.; Qin, J.-L.; Liu, Y.-C.; Huang, K.-B.; Li, Y.-L.; Meng, T.; Zhang, G.-H.; Peng, Y.; Luo, X.-J.; et al. Stabilization of G-quadruplex DNA, inhibition of telomerase activity, and tumor cell apoptosis by organ platinum(II) complexes with oxoisoaporphine. J. Med. Chem. 2015, 58, 2159-2179. [CrossRef] [PubMed]

20. Qin, J.-L.; Qin, Q.-P.; Wei, Z.-Z.; Yu, C.-C.; Meng, T.; Wu, C.-X.; Liang, Y.-L.; Liang, H.; Chen, Z.-F. Stabilization of c-myc G-quadruplex DNA, inhibition of telomerase activity, disruption of mitochondrial functions and tumor cell apoptosis by platinum(II) complex with 9-amino-oxoisoaporphine. Eur. J. Med. Chem. 2016, 124, 417-427. [CrossRef] [PubMed] 
21. Qin, Q.-P.; Qin, J.-L.; Meng, T.; Lin, W.-H.; Zhang, C.-H.; Wei, Z.-Z.; Chen, J.-N.; Liu, Y.-C.; Liang, H.; Chen, Z.-F. High in vivo antitumor activity of cobalt oxoisoaporphine complexes by targeting G-quadruplex DNA, telomerase and disrupting mitochondrial functions. Eur. J. Med. Chem. 2016, 124, 380-392. [CrossRef] [PubMed]

22. Zhang, Q.; Kim, N.K.; Feigon, J. Architecture of human telomerase RNA. Proc. Natl. Acad. Sci. USA 2011, 108, 20325-20332. [CrossRef] [PubMed]

23. Jansson, L.I.; Akiyama, B.M.; Ooms, A.; Lu, C.; Rubin, S.M.; Stone, M.D. Structural basis of template-boundary definition in Tetrahymena telomerase. Nat. Struct. Mol. Biol. 2015, 22, 883-888. [CrossRef] [PubMed]

24. Singh, M.; Wang, Z.; Koo, B.K.; Patel, A.; Cascio, D.; Collins, K.; Feigon, J. Structural basis for telomerase RNA recognition and RNP assembly by the holoenzyme La family protein p65. Mol. Cell 2012, 47, 16-26. [CrossRef] [PubMed]

25. Bryan, C.; Rice, C.; Hoffman, H.; Harkisheimer, M.; Sweeney, M.; Skordalakes, E. Structural basis of telomerase inhibition by the highly specific BIBR1532. Structure 2015, 23, 1-9. [CrossRef] [PubMed]

26. Gavory, G.; Symmons, M.F.; Krishnan Ghosh, Y.; Klenerman, D.; Balasubramanian, S. Structural analysis of the catalytic core of human telomerase RNA by FRET and molecular modeling. Biochemistry 2006, 45, 13304-13311. [CrossRef] [PubMed]

27. Holt, S.E.; Wright, W.E.; Shay, J.W. Regulation of telomerase activity in immortal cell lines. Mol. Cell. Biol. 1996, 16, 2932-2939. [CrossRef] [PubMed]

28. Zhu, X.; Kumar, R.; Mandal, M.; Sharma, N.; Sharma, H.W.; Dhingra, U.; Sokoloski, J.A.; Hsiao, R.; Narayanan, R. Cell cycle-dependent modulation of telomerase activity in tumor cells. Proc. Natl. Acad. Sci. USA 1996, 93, 6091-6095. [CrossRef] [PubMed]

29. Reed, J.E.; Arnal, A.A.; Neidle, S.; Vilar, R. Stabilization of G-quadruplex DNA and inhibition of telomerase activity by square-planar nickel(II) complexes. J. Am. Chem. Soc. 2006, 128, 5592-5993. [CrossRef] [PubMed]

30. Meng, T.; Tang, S.-F.; Qin, Q.-P.; Liang, Y.-L.; Wu, C.-X.; Wang, C.-Y.; Yan, H.-T.; Dong, J.-X.; Liu, Y.-C. Evaluation of the effect of iodine substitution of 8-hydroxyquinoline on its platinum(II) complex: Cytotoxicity, cell apoptosis and telomerase inhibition. Med. Chem. Commun. 2016, 7, 1802-1811. [CrossRef]

31. Cole, D.K.; Rizkallah, P.J.; Gao, F.; Watson, N.I.; Boulter, J.M.; Bell, J.I.; Sami, M.; Gao, G.F.; Jakobsen, B.K. Crystal structure of HLA-A* 2402 complexed with a telomerase peptide. Eur. J. Immunol. 2006, 36, 170-179. [CrossRef] [PubMed]

32. Chen, J.-N.; Wang, X.-F.; Li, T.; Wu, D.-W.; Fu, X.-B.; Zhang, G.-J.; Shen, X.-C.; Wang, H.-S. Design, synthesis, and biological evaluation of novel quinazolinyl-diaryl urea derivatives as potential anticancer agent. Eur. J. Med. Chem. 2016, 107, 12-25. [CrossRef] [PubMed]

Sample Availability: Samples of the compounds $\mathrm{H}-\mathrm{L}^{\mathrm{a}}$ and $\mathrm{H}-\mathrm{L}^{\mathrm{b}}$ are available from the authors.

(C) 2016 by the authors; licensee MDPI, Basel, Switzerland. This article is an open access article distributed under the terms and conditions of the Creative Commons Attribution (CC-BY) license (http://creativecommons.org/licenses/by/4.0/). 